\title{
PENGARUH STATUS GIZI TERHADAP KEJADIAN ANEMIA PADA IBU HAMIL DI DAERAH ENDEMIK MALARIA KOTA BENGKULU
}

\section{THE INFLUENCE OF NUTRITIONAL STATUS ON EVENT OF ANEMIA IN PREGNANT MOTHERS IN MALARIA ENDEMIC AREAS BENGKULU CITY}

\author{
Aguscik, Ridwan \\ Jurusan Keperawatan Poltekkes Kemenkes Palembang, Sumatera Selatan, Indonesia \\ (email penulis korespondensi: aguscik@ poltekkespalembang.ac.id)
}

\begin{abstract}
ABSTRAK
Latar Belakang: Status gizi adalah keadaan tubuh sebagai akibat konsumsi makanan dan penggunaan zat-zat gizi yang dapat dibedakan antara gizi buruk, kurang baik dan lebih. Status gizi dan tingkat anemia ibu khususnya pada ibu hamil mempunyai peranan penting bagi pertumbuhan janin dalam kandungan. Status gizi pada ibu hamil dapat dijabarkan dengan pengukuran LILA di daerah endemik malaria, adanya malaria sering tumpang tindih dengan kejadian gizi buruk pada ibu hamil. Penelitian ini bertujuan untuk mengetahui apakah ada hubungan antara status gizi dengan tingkat anemia pada ibu hamil di Daerah endemik malaria Kota bengkulu.

Metode: Penelitian dilakukan dengan desain penelitian cross sectiona dan teknik pengambilan sampel Accidental Sampling. Jumlah sampel 40 ibu hamil yang merupakan total populasi. Data diuji dengan Shapiro-Wilk.

Hasil: Hasil penelitian menunjukkan bahwa status gizi (LILA) ibu hamil rata-rata 21,54 $\pm 0,884$ (berisiko), ibu hamil menderita KEK 60\% dan yang tidak beresiko KEK $40 \%$ dimana pvalue 0,003. Keseimpulan: Terdapat hubungan yang bermakna antara status gizidengan tingkat anemia pada ibu hamil di daerah endemik malaria, kota Bengkulu.
\end{abstract}

Kata kunci : Status gizi, Anemia, Ibu hamil, Malaria.

\section{ABTRACT}

Introduction: Nutrion status was a state of the body as the result of the consumption of food and the nutrients used which could be differentiate into poor nutrition, poorly and more. The nutrition status and the level of maternal anemia, especially in pregnant women had an important role for the growth of the fetus in the womb. Nutrition status in pregnant women could be described with LILA measurements in malaria endemic areas, the presence of malaria often overlap with the incidence of malnutrition in pregnant women. This research aim was to determine whether there was a relationship between nutrition status with the level of anemia on pregnant women in malaria-endemic areas of the Bengkulu's city.

Methods: The study was conducted with a cross sectional research design and accidental sampling techniques. Total samplee were 40 pregnant women. Data were tested by Shapiro - Wilk.

Result: The results of this research showed that the nutrition status (LILA) of pregnant women on average 21.54 was \pm 0.884 ( risk), pregnant women who suffering from the KEK was $60 \%$ and the rest $40 \%$ were not at risk of KEK where $p$ value was 0.003 . Conclusion: there was a significant relationship between nutrition status and the level of anemia on pregnant women in endemic-malaria areas of the Bengkulu's city.

Keywords : Nutrition Status, Anemia, Pregnant Women, Malaria 


\section{PENDAHULUAN}

Status gizi ibu sebelum hamil mempunyai pengaruh yang bermakna terhadap kejadian Berat Bayi Lahir Rendah (BBLR). Ibu dengan status gizi kurang baik sebelum hamil mempunyai angka kejadian 4,27 kali untuk melahirkan bayi dengan resiko BBLR dibandingkan dengan ibu yang mempunyai status gizi baik (normal). ${ }^{2}$ Masalah BBLR terkait dengan kondisi kesehatan ibu saat hamil, termasuk kondisi status gizi ibu menggambarkan konsumsi energi dan protein yang tidak adekuat. Berat bayi lahir adalah cerminan dari status kesehatan dan gizi selama hamil serta pelayanan antenatal yang diterima ibu. Ibu hamil dengan anemia merupakan suatu kondisi penurunan kadar hemoglobin dan jumlah eritrosit dibawah nilai normal pada ibu hamil.

Prevalensi anemia meningkat sebesar 15 $20 \%$ dengan kehamilan yang disebabkan karena sebelum wanita mengalami kehamilan mereka telah jatuh pada keadaan anemia. Kekurangan gizi pada ibu hamil dan perhatian yang kurang merupakan predisposisi anemia ibu hamil di Indonesia. Anemia akan meningkat resiko terjadi kematian ibu 3,7 kali lebih tinggi jika dibandingkan ibu yang tidak anemia. ${ }^{8,9}$ Masalah gizi yang dialami ibu hamil saat ini adalah gizi kurang seperti Kurang Energi Kronis (KEK) dan anemia gizi. Status gizi ibu hamil dapat diukur dengan dengan Lingkar Lengan Atas (LILA) < $23,5 \mathrm{~cm}$ untuk LILA yang beresiko dan $\geq 23,5$ untuk LILA tidak beresiko. ${ }^{8}$

Lingkar lengan atas dan kadar Hemoglobin ibu hamil mempunyai peranan penting dalam pertumbuhan dan perkembangan janin. Konsumsi makanan yang kurang dan

\section{METODE}

Penelitian ini merupakan penelitian observasional analitik menggunakan desain cross sectional. Pelaksanaan penelitian pada bulan Agustus 2017 di Kota Bengkulu dan yang menjadi subjek penelitian adalah ibu - ibu hamil yang berada di daerah endemis malaria. Sampel

\section{HASIL}

Hasil analisis univariat status anemia ibu hamil yang diperiksa di Kota Bengkulu penyakit yang dialami ibu hamil akan berakibat buruk terhadap perkembangan atau pertumbuhan janin. Pada ibu hamil diperlukan tambahan konsumsi protein untuk pembentukan sel darah merah yang berguna untuk membantu pertumbuhan janin.

Anemia pada ibu hamil juga dapat disebabkan oleh penyakit malaria terutama ibu hamil yang tinggal didaerah dengan penyebaran malaria tinggi. Wanita hamil yang berada didaerah endemik malaria beresiko tinggi terkena infeksi. Salah satu daerah endemik malaria di Indonesia adala provinsi Bengkulu, pada tahun 2009 terdapat 53.912 kasus malaria dan diantaranya terdapat 230 penderita merupakan ibu hamil. Pada tahun 2011 menjadi 61.477 kasus diantaranya terdapat 87 kasus pada ibu hamil. $^{13,14}$

Infeksi malaria pada kehamilan sangat merugikan baik bagi ibu dan janin yang dikandungnya, karena infeksi malaria ini dapat meningkatkan kejadian morbiditas dan mortalitas ibu hamil maupun janin. Pada ibu infeksi malaria dapat menyebabkan terjadinya anemia, edema paru, malaria serebral, gagal ginjal bahkan dapat menyebabkan kematian bagi ibu. Pada janin dapat menyebabkan persalinan premature, abortus, BBLR dan kematian bagi janin. ${ }^{15}$

Berdasarkan fenomena di atas dengan disertai data-data dan fakta-fakta, maka penulis tertarik untuk melakukan penelitian di Kota Bengkulu untuk mengetahui hubungan antara status gizi dengan tingkat anemia pada ibu hamil di daerah endemik malaria.

diambil dengan teknik acak sederhana, dengan besar sampel sebanyak 40 responden. Data anemia diambil dengan cara pemeriksaan kadar hemoglobin yang dilakukan pada ibu hamil, sedangkan LILA diukur menggunakan pita meter.

dijelaskan pada Tabel 1 dan hasil analisis bivariat dijelaskan pada Tabel 2 dibawah ini: 
Tabel 1. Distribusi Frekuensi Status Anemia dan LILA Pada Ibu Hamil (n=40)

\begin{tabular}{lccc}
\hline Variabel & n & $\begin{array}{c}\text { Persentase } \\
(\boldsymbol{\%})\end{array}$ & Mean \pm SD \\
\hline Status Anemia & 20 & 50 & $11,53 \pm 0,612$ \\
1. Normal & 20 & 50 & $9,70 \pm 0,571$ \\
$\begin{array}{l}\text { 2. Ringan } \\
\text { 3. Berat }\end{array}$ & 0 & 0 & - \\
$\begin{array}{l}\text { LILA } \\
\text { 1. Tidak Beresiko }\end{array}$ & 16 & 40 & $24,67 \pm 0,724$ \\
$\quad$ KEK & & 60 & $21,54 \pm 0,884$ \\
2. Berisiko KEK & 24 & & \\
\hline
\end{tabular}

Tabel 2. Hubungan Status Gizi dengan Tingkat Anemia Pada Ibu Hamil di Daerah Endemik Malaria Kota Bengkulu (n=40)

\begin{tabular}{llllllll}
\hline \multirow{2}{*}{ Status Anemia } & \multicolumn{4}{c}{ Status Gizi } & \multicolumn{2}{c}{ Jumlah } & pvalue \\
\cline { 2 - 6 } & \multicolumn{2}{c}{$\begin{array}{c}\text { Tidak berisiko } \\
\text { KEK }\end{array}$} & \multicolumn{2}{c}{ Berisiko } & n & \% & \\
\cline { 2 - 6 } & n & $\%$ & n & \% & & & \\
\hline 1. Normal & 13 & 65 & 7 & 35 & 20 & 100 & 0,003 \\
2. Ringan & 3 & 15 & 17 & 85 & 20 & 100 & \\
\hline
\end{tabular}

Berdasarkan Tabel 1 diperolehibu hami yang mengalami anemia ringan sebanyak 20 responden $(50 \%)$ dan LILA yang berisiko KEK sebanyak 24 responden (60\%). Pada Tabel 2

\section{PEMBAHASAN}

Hasil uji statistik dengan chi square menunjukkan ada hubungan bermakna antara status anemia LILA ibu hamil di daerah endemik malaria Kota Bengkulu. Pemeriksaan kadar HB (Haemoglobin) pada ibu hamil juga menentukan apakah ibu hamil tersebut menderita anemia atau tidak. Batas normal kadar HB pada wanita dewasa adalah 12-14 mg/dl, sedangkan pada wanita hamil dengan kadar HB $11 \mathrm{mg} / \mathrm{dl}$ masih dianggap normal. Bila $<11 \mathrm{mg} / \mathrm{dl}$ dinyatakan sebagai anemia. Anemia ibu hamil dapat mengganggu pertumbuhan janin dalam kandungan. $^{23}$

Penyebab anemia adalah kurang gizi, kurang zat besi, kehilangan darah saat persalinan yang lalu, dan penyakit - penyakit kronik. Dalam kehamilan penurunan kadar hemoglobin yang dijumpai selama kehamilan disebabkan oleh karena dalam kehamilan keperluan zat makanan bertambah dan terjadinya perubahan-perubahan dalam darah : penambahan volume plasma yang relatif lebih besar dari pada penambahan massa hemoglobin dan volume sel darah merah. ${ }^{9}$ menunjukkan bahwa secara statistik terdapat hubungan antara status gizi dengan status anemia ibu hamil di daerah endemik malaria Kota Bengkulu.
Penelitian ini didukung oleh penelitian yang dilakukan Marlapan ${ }^{1}$, diperoleh hasil bahwa ibu hamil yang melakukan pemeriksaan ANC sangat bermanfaat bagi kesehatan ibu dan calon bayi. Bagi ibu yang mengalami pengalaman kehamilan pertama dapat diberikan edukasi mengenai perencanaan pengaturan gizi selama masa kehamilan dan juga melalui ANC yang teratur dapat mendeteksi secara dini kejadian anemia. Oleh karena itu dengan pemeriksaan ANC secara teratur dapat merawat dan mempersiapkan dirinya dalam persalinan dan mencegah terjadinya anemia.

LILA dapat digunakan untuk mengetahui status gizi ibu hamil terutama berkaitan dengan KEK. Saat ini, penggunaan LILA ssebagai indikator resiko KEK telah banyak digunakan di negara-negara berkembang termasuk Indonesia. Status gizi ibu hamil bisa diketahui dengan mnegukur ukuran LILA, bila $<23,5 \mathrm{~cm}$ maka ibu hamil termasuk KEK ini berarti ibu sudah mengalami keadaan kurang gizi dalam jangka waktu yang telah lama, bila ini terjadi maka kebutuhan nutrisi untuk proses tumbuh kembang 
janin makin terhambat, akibatnya bayi yang dilahirkan menderita BBLR. ${ }^{22}$

Ibu hamil dinyatakan KEK apabila memiliki batas ambang pengukuran LILA $<23,5$ $\mathrm{cm}$, hal ini berarti ibu hamil dengan resiko KEK diperkirakan akan melahirkan bayi BBLR. Kejadian KEK tersebut disebabkan karena ketidakseimbangan asupan gizi, sehingga zat gizi yang dibutuhkan tubuh ibu hamil tidak dapat tercukupi. Penambahan 200 - 450 kalori per hari dan 12 - 20 gram per hari protein dari kebutuhan ibu hamil adalah angka yang mencukupi untuk memenuhi kebutuhan gizi janin. ${ }^{16}$

Implikasi ukuran LILA terhadap berat bayi lahir adalah bahwa LILA menggambarkan keadaan konsumsi makanan terutama konsumsi energi dan protein dalam jangka panjang. Kekurangan energi secara kronis ini disebabkan

\section{KESIMPULAN DAN SARAN}

Status anemia berhubungan dengan dengan LILA ibu hamil di daerah endemik malaria Kota Bengkulu. Oleh karena itu perlu dilakukan upaya

\section{DAFTAR PUSTAKA}

1. Marlapan, S., Wantouw, B., Sambeka, J.2013. Hubungan Status Gizi Dengan Kejadian Anemia Pada Ibu Hamil Di Wilayah Kerja Puskesmas Tumuning Kec.Tumunting Kota Manado Tahun 2013. Manado: Universitas Sam Ratulangi.

2. Triwidiyanti, D., Sabarudin, U., Anwar, R. 2011. Hubungan Status Gizi dengan Anemia pada Ibu Hamil Trimester III di Puskesmas Garuda Kota Bandung. Jurnal Pendidikan Bidan.

http://www.jurnalpendidikanbidan.com/.

Diakses 24 September 2013

3. Departemen Kesehatan RI. 2007. Pedoman Pengukuran dan Pemeriksaan. Jakarta. Diakses dari http://www.profile dinaskesehatan kota jakarta.ac.id diakses 2 oktober 2013

4. Darmono. 2009. Status Gizi Pada Awal Kehamilan Studi di Kabupaten Demak tahun 2009. Thesis. Semarang: Universitas Diponegoro.

5. Dinas Kesehatan Bengkulu. 2010. Laporan tahunan penemuan dan pengobatan malaria provinsi bengkulu 2009. Bengkulu : Dinkes ibu hamil tidak mempunyai cadangan zat gizi yang adekuat untuk menyediakan kebutuhan fisiologi kehamilan yakni perubahan hormon dan meningkatkan volume darah untuk pertumbuhan janin, sehingga suplai zat gizi pada janinpun berkurang. Akibatnya pertumbuhan dan perkembangan janin terhambat dan lahir dengan berat yang rendah.

Hasil ini didukung oleh pendapat Yuniati $(2003)^{47}$ yang mengatakan bahwa LILA dan kadar Hemoglobin ibu hamil mempunyai peranan penting dalam perkembangan dan pertumbuhan janin. Pada ibu hamil yang menderita KEK akan menyebabkan ukuran plasenta lebih kecil dan suplai nutrisi dari ibu ke janin berkurang, sehingga terjadi retardasi perkembangan janin intra uteria dan bayi dengan berat lahir rendah. ${ }^{48}$

pencegahan pada ibu hamil untuk mengkonsumsi tablet besi.

6. Dinas Kesehatan Bengkulu. 2012. Laporan Tahunan Penemuan Dan Pengobatan Malaria Provinsi Bengkulu 2011. Bengkulu

7. Chahaya, Indra. 2003. Pengaruh Malaria Selama Kehamilan. Medan : Bagian Kesehatan Lingkungan, FKM USU.

8. Lubis, Z. 2003. Status Gizi Ibu Hamil Serta Pengaruhnya terhadap Bayi Yang dilahirkan. Pengantar falsafah sains (PPS702) Program Pasca Sarjana S3 IPB November 2003, Bogor.

9. Supariasa, I., Bakrie, B., Fajar, L. 2002. Penilaian Status Gizi. Jakarta: EGC.

10. Notoatmodjo, S.2010. Metodologi Penelitian Kesehatan. Jakarta : Rineka Cipta

11. Sopiyudin, M. D. 2012. Statistik Untuk Kedokteran dan Kesehatan. Jakarta: Salemba Medika.

12. Antarini, Y. 2003. Hubungan Status Gizi (LILA dan Kadar Haemoglobin) Ibu Hamil Trimester III Dengan Berat Lahir Bayi. 